\title{
A hybrid of B and T lymphoblastic cell line could potentially substitute dendritic cells to efficiently expand out Her-2/neu-specific cytotoxic $T$ lymphocytes from advanced breast cancer patients in vitro
}

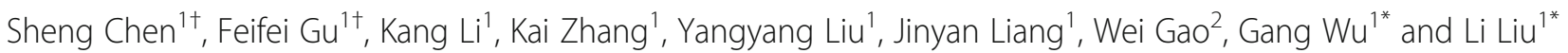

\begin{abstract}
Adoptive transfer of cytotoxic T lymphocytes (CTLS) holds promises to cure cancer. However, this treatment is hindered by lacking a robust way to specifically expand out CTLs. Here, we developed a hybrid of B lymphoblastic cell line and T lymphoblastic cell line (T2 cells) as a substitute of dendritic cells, together with irradiated autologous peripheral blood mononuclear cell (PBMC) as feeder cells and rhIL-2, to activate and expand Her-2/neu-specific CD8 ${ }^{+} \mathrm{T}$ cells from human epidermal growth factor receptor 2 (Her-2/neu) and human leukocyte antigen (HLA)-A2 double positive advanced breast cancer patients in vitro. These Her-2/neu-loaded T2 cells reproducibly activated and expanded out Her-2/neu-specific CD8 ${ }^{+} T$ cells to $10^{7}$ in 8 weeks. Furthermore, these Her-2/neu-specific CD ${ }^{+} \mathrm{T}$ cells had good sensitivity of recognition and killing Her-2/neu-overexpressed breast cancer cell line SK.BR.3. This technique gives us another insight on how to rapidly obtain sufficient CTLs for adoptive cancer immunotherapy.
\end{abstract}

Keywords: Hybrid of B and T lymphoblastic cell line, Adoptive cancer immunotherapy, Cytotoxic T lymphocytes, Breast cancer

To the editor

The current standard way to expand specific cytotoxic $\mathrm{T}$ lymphocytes (CTLs) replies obtaining sufficient dendritic cells (DCs) from patients (Additional file 1). This method has several defects such as invasive, time-consuming, expansive, and unstable according to patients' physical conditions [1-5]. Our group found that the T2 cells, which are a cloned hybrid between the 721.174 (variant of the B lymphoblastic cell line LCL 721) and $\mathrm{CEM}^{\mathrm{R}} .3$ (variant of $\mathrm{T}$ lymphoblastic cell line CEM-C7), potentially conform to the demands. The cells are TAP and MHC class II deficient, but they do express HLA-A2 and massive co-stimulatory molecules (Additional file 2: Figure S1). These characters make T2 cells potentially

\footnotetext{
* Correspondence: xhzlwg@163.com; liulist2013@163.com

${ }^{\dagger}$ Equal contributors

${ }^{1}$ Cancer Center, Union Hospital, Tongji Medical College, Huazhong University of Science and Technology, Wuhan 430022, China

Full list of author information is available at the end of the article
}

useful to study $\mathrm{CD}^{+} \mathrm{T}$ cell recognition of MHC class I antigens, meanwhile, convenient to exclude from MHC class II antigen intervention. Subsequently,

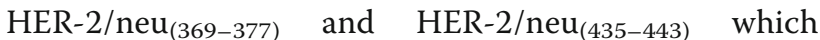
scores more than 20 by SYFPEITHI prediction was selected to load to T2 cells to expand Her-2/neu-specific $\mathrm{CD}^{+} \mathrm{T}$ cells. HIV $\operatorname{gag}_{(77-85)}$, insulin B chain ${ }_{(34-42)}$, and

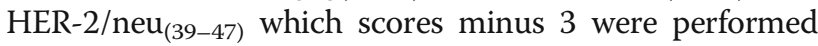
as a control (see Additional file 1: Table S1). All peptides except low-affinity peptide HER-2/neu $(39-47)$ could stabilize HLA-A2 molecules on the cell membrane obviously (Additional file 3: Figure S2A).

After co-culture with $\mathrm{CD}^{+} \mathrm{T}$ cells from $\mathrm{Her}-2 /$ neu and HLA-A2 double positive advanced breast cancer patients, HER-2/neu (369-377) $^{-}$and HER-2/neu ${ }_{(435-443)^{-}}$ loaded T2 cells lead to a large secretion of IFN- $\gamma$, but not the three controls (Additional file 3: Figure S2B).

For the expansion, starting from $1 \times 10^{5}$ total $\mathrm{CD}^{+} \mathrm{T}$ cells that were less than $0.05 \% \mathrm{Her}-2 /$ neu-specific, nearly 
$10^{7}$ HER-2/neu (369-377) or HER-2/neu (435-443)-specific $\mathrm{CD}^{+} \mathrm{T}$ cells were expanded out in 8 weeks with the purity of around $85 \%$ (Fig. 1a, b). The expanded specific $\mathrm{CD} 8{ }^{+} \mathrm{T}$ cells got massive co-stimulatory molecules and activation makers (Fig. 1c). The three controls got negative results. That was expected due to extremely low frequency of naturally occurring HIV gag (77-85) and insulin $\mathrm{B}$ chain $_{(34-42)}$-specific naive $\mathrm{CD}^{+} \mathrm{T}$ cells as

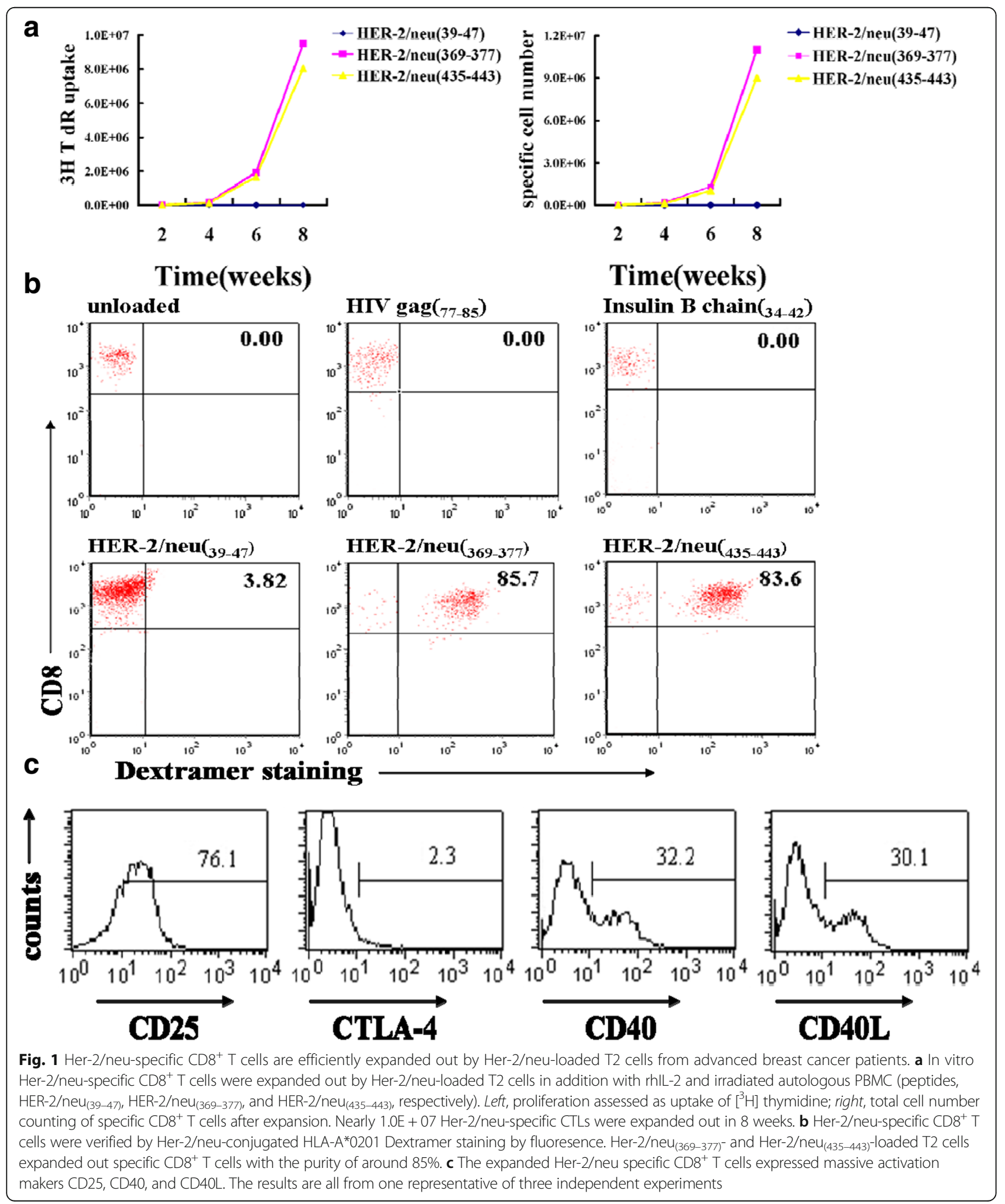


indicated in Additional file 3: Figure S2B and low

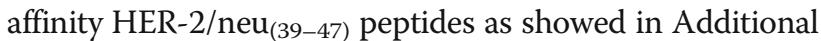
file 1: Table S1. We found these expanded HER-2/neuspecific $\mathrm{CD}^{+} \mathrm{T}$ cells were mainly effector and effector memory cells (Additional file 4: Figure S3).

The expanded Her-2/neu-specific CTL populations mediated dose-dependent lysis to HLA-A2-positive and Her-2/neu-overexpressed breast cancer cell line SK.BR.3, but not to the three control targets (Fig. 2a). The lysis attributed to over $50 \%$ perforin producing CTLs and more than $80 \%$ granzyme B producing CTLs (Fig. 2b). The cytotoxic activity against SK.BR.3 could significantly be eliminated by W6/32, but not by IgG2 (shown in Fig. 2c).

A major finding of this study was that the Her- $2 /$ neuloaded T2 cells could expand out nearly $10^{7} \mathrm{Her}-2 /$ neuspecific CTLs in 8 weeks. The expanding efficiency is equivalent to DCs previously reported by Marzocchetti et al. [6-8]. And because the expansion was started from

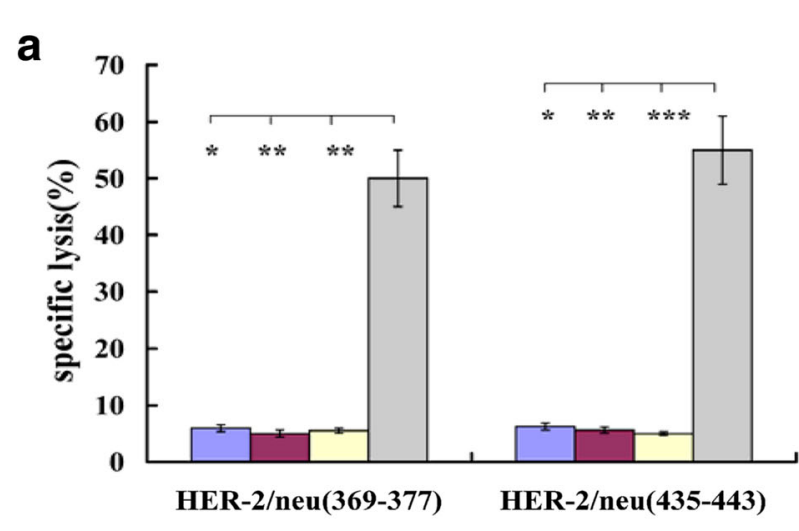

b

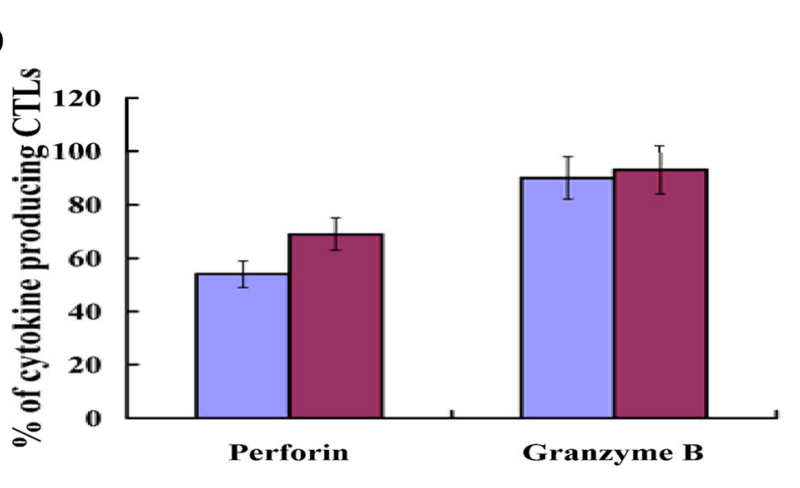

C

口HER-2/neu(369-377)

$\square$ HER-2/neu(435-443)

\section{$\square$ PC-9 \\ $\square$ SW480 \\ $\square$ MDA-MB-231 \\ $\square$ SK.BR.3}

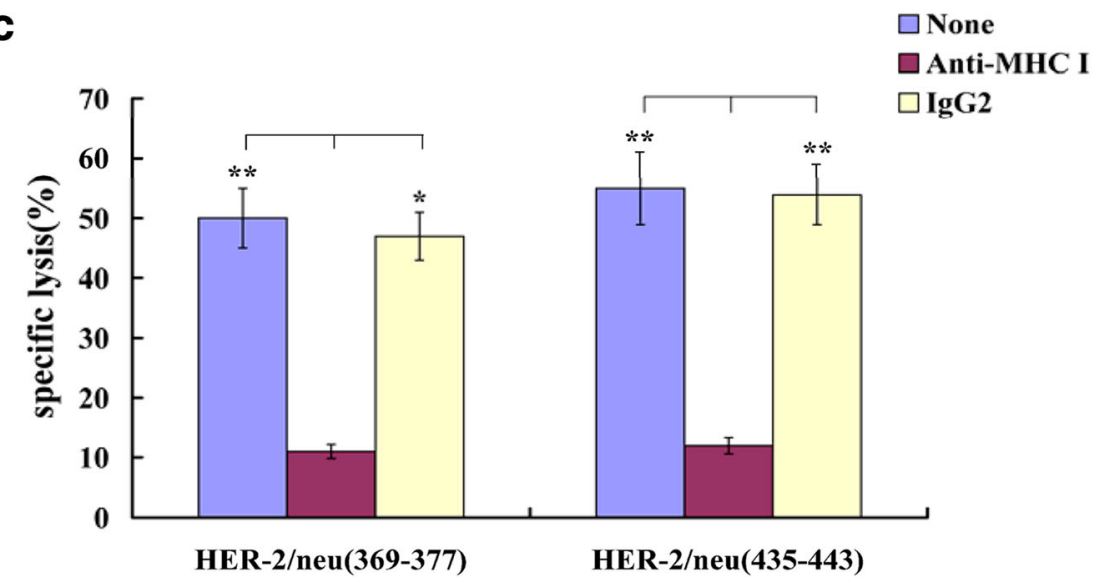

Fig. 2 The expanded Her2/neu-specific CTLs well recognize and kill the related targets. a The expanded effector cells (HER-2/neu $(369-377)$-Or HER-2/ neu (435-443)-Specific CD8 $^{+} \mathrm{T}$ cells) could only lyse HLA-A2-positive and Her-2/neu-overexpressed breast cancer cell line SK.BR.3, but not the controls. b Perforin or granzyme B secretion by expanded Her2/neu-specific effector cells was detected after co-culture with SK.BR.3. c Anti-HLA class I antibody blocking inhibited the cytotoxic activity of the expanded Her-2/neu-specific CD8 ${ }^{+} \mathrm{T}$ cells against SK.BR.3. Mouse lgG2 antibody was added as a control. ${ }^{*} P<0.05$, ${ }^{*} P<0.01,{ }^{* *} P<0.001$ (ANOVA) 
$\mathrm{CD}^{+} \mathrm{T}$ cells which were only from $5 \mathrm{ml}$ blood, with an initial frequency of Her-2/neu-specific $\mathrm{CD}^{+} \mathrm{T}$ cells at $0.05 \%$, it would be possible to amplify the expanding quantity if we isolate the Her-2/neu-specific $\mathrm{CD}^{+} \mathrm{T}$ cells firstly from more blood, $50 \mathrm{ml}$ or more for example.

We found the expanded HER-2/neu-specific CTLs could recognize endogenous antigen on allogeneic breast cancer cell line SK.BR.3. This is critically important because previously, many expanding techniques lead to CTLs that could only kill targets pulsed with related peptides but not targets that endogenously processed the antigen of interest [9]. Yee et al. [10, 11] found low affinity of induced CTLs leads to failure of recognition of endogenous antigen.

Thus, T2 cells have shown promise as a convenient tool to rapidly expand out Her-2/neu-specific CTLs in vitro. But so far, we are not able to transfer the expanded Her-2/neu-specific CTLs to breast cancer patients directly as they are mixed with T2 cells, and for the same reason, we cannot compare its anti-tumor effect with trastuzumab in breast cancer patients either. This technique might accelerate to study expanding CTLs in vitro and promote the development of safe and effective adoptive cancer immunotherapy in the future.

\section{Additional files}

Additional file 1: Materials and methods. (DOC $199 \mathrm{~kb}$ )

Additional file 2: Figure S1. T2 cells express more HLA-A2 and equivalent co-stimulatory molecules compared with DC cells. (TIF $173 \mathrm{~kb}$ )

Additional file 3: Figure S2. Her-2/neu-loaded T2 cells can activate related $C D 8^{+} \mathrm{T}$ cells equally as DCs. a T2 cells stabilized the $\mathrm{MHC}$ । molecules on the cell membrane after loading relative restricted peptides. The mean fluorescence intensity of HLA-A2 was detected by FACS staining before or after peptide loading. b Her-2/neu-loaded T2 cells could activate CD8 ${ }^{+} T$ cells as effectively as DC cells. IFN- $\gamma$ secretion of $\mathrm{CD}^{+} \mathrm{T}$ cells after activation was detected by ELISA. ${ }^{*} P<0.05,{ }^{* *} P<$ 0.01 (Student's $t$ test). (TIF $14741 \mathrm{~kb}$ )

Additional file 4: Figure S3. The expanded Her-2/neu-specific CD8 ${ }^{+} \mathrm{T}$ cells are mainly effector and effector memory cells. CCR7 and CD45RA expression on expanded $\mathrm{CD}^{+} \mathrm{T}$ cells was detected by FACS. The expanded Her-2/neu specific CTLs were partially CCR7 ${ }^{-}$CD45RA ${ }^{+}$(effector), partially $\mathrm{CCR}^{-} \mathrm{CD}^{-} 5 \mathrm{RA}^{-}$(effector memory), and rarely (about 1.62\%) CCR7 ${ }^{+} \mathrm{CD} 45 \mathrm{RA}^{+}$ (naive). This representative data are from the expanded $\mathrm{Her}-2 /$ neu $_{(369-377)^{-}}$ specific CD8 ${ }^{+}$T cells. (TIF 11635 kb)

\section{Abbreviations}

CCR7: C-C chemokine receptor type 7; CD45: Cluster of differentiation 45; CTLs: Cytotoxic T lymphocytes; DCs: Dendritic cells; Her-2/neu: Human epidermal growth factor receptor 2; HIV: Human immunodeficiency virus; HLA: Human leukocyte antigen; IL-2: Interleukin-2; MHC: Major histocompatibility complex; PBMC: Peripheral blood mononuclear cell; TCR: T cell receptor

\section{Acknowledgements}

Not applicable.

\section{Funding}

This work was supported by the National Natural Sciences Foundation of China (NO: 81000911, 81372260, 81300586).

\section{Availability of data and materials}

The dataset supporting the conclusions of this article is available in the SYFPEITHI repository, http://www.syfpeithi.de/bin/MHCServer.dll/

EpitopePrediction.htm.

\section{Authors' contributions}

SC, LL, and GW conceived and designed the study. SC wrote the manuscript. $\mathrm{KL}$ and $\mathrm{FG}$ performed the experiments. FG collected and assembled the data.

WG performed the statistical analysis. LL reviewed the manuscript. All

authors approved the final manuscript.

\section{Competing interests}

The authors declare that they have no competing interests.

\section{Consent for publication}

Not applicable.

\section{Ethics approval and consent to participate}

The study was reviewed and approved in 2010 by the Ethics Committee of Tongji Medical College, Huazhong University of Science and Technology. All subjects were performed in accordance with the medical experiment guidelines of Huazhong University of Science and Technology, which abides by the Helsinki Declaration on ethical principles for medical research involving human subjects. Written informed consent to participate under the ethics, consent, and permissions was obtained from all ten patients.

\section{Author details}

${ }^{1}$ Cancer Center, Union Hospital, Tongji Medical College, Huazhong University of Science and Technology, Wuhan 430022, China. ${ }^{2}$ Traumatology

Department, Tongji Hospital, Tongji Medical College, Huazhong University of Science and Technology, Wuhan 430022, China.

Received: 7 January 2017 Accepted: 23 February 2017

Published online: 28 February 2017

References

1. Teague RM, Sather BD, Sacks JA, Huang MZ, Dossett ML, Morimoto J, Tan X, Sutton SE, Cooke MP, Ohlén C, Greenberg PD. Interleukin-15 rescues tolerant $C D 8^{+} \mathrm{T}$ cells for use in adoptive immunotherapy of established tumors. Nat Med. 2006;12(3):335-41.

2. Disis ML, Bernhard H, Jaffee EM. Use of tumour-responsive T cells as cancer treatment. Lancet. 2009;373(9664):673-83.

3. Vignard V, Lemercier B, Lim A, Pandolfino MC, Guilloux Y, Khammari A, Rabu C, Echasserieau K, Lang F, Gougeon ML, Dreno B, Jotereau F, Labarriere N. Adoptive transfer of tumor-reactive Melan-A-specific CTL clones in melanoma patients is followed by increased frequencies of additional Melan-A-specific T cells. J Immunol. 2005;175(7):4797-805.

4. Yee C, Thompson JA, Byrd D, Riddell SR, Roche P, Celis E, Greenberg PD. Adoptive $T$ cell therapy using antigen-specific CD8+ T cell clones for the treatment of patients with metastatic melanoma: in vivo persistence, migration, and antitumor effect of transferred T cells. Proc Natl Acad Sci U S A. 2002;99(25):16168-73.

5. Almand B, Resser JR, Lindman B, Nadaf S, Clark Jl, Kwon ED, Carbone DP, Gabrilovich DI. Clinical significance of defective dendritic cell differentiation in cancer. Clin Cancer Res. 2000;6(5):1755-66.

6. Marzocchetti A, Lima M, Tompkins T, Kavanagh DG, Gandhi RT, O'Neill DW Bhardwaj N, Koralnik IJ. Efficient in vitro expansion of JC virus-specific CD8(+) Tcell responses by JCV peptide-stimulated dendritic cells from patients with progressive multifocal leukoencephalopathy. Virology. 2009;383(2):173-7.

7. Tuettenberg A, Jonuleit $H$, Tüting T, Brück J, Knop J, Enk AH. Priming of T cells with Ad-transduced DC followed by expansion with peptide-pulsed DC significantly enhances the induction of tumor-specific CD8+ T cells: implications for an efficient vaccination strategy. Gene Ther. 2003;10(3):243-50.

8. Wolfraim LA, Takahara M, Viley AM, Shivakumar R, Nieda M, Maekawa R, Liu LN, Peshwa MV. Clinical scale electroloading of mature dendritic cells with melanoma whole tumor cell lysate is superior to conventional lysate coincubation in triggering robust in vitro expansion of functional antigenspecific CTL. Int Immunopharmacol. 2013;15(3):488-97.

9. Heiser A, Coleman D, Dannull J, Yancey D, Maurice MA, Lallas CD, Dahm P, Niedzwiecki D, Gilboa E, Vieweg J. Autologous dendritic cells transfected 
with prostate-specific antigen RNA stimulate CTL responses against metastatic prostate tumors. J Clin Invest. 2002;109(3):409-17.

10. Yee C, Savage PA, Lee PP, Davis MM, Greenberg PD. Isolation of high avidity melanoma-reactive CTL from heterogeneous populations using peptideMHC tetramers. J Immunol. 1999;162(4):2227-34.

11. Gritzapis AD, Mahaira LG, Perez SA, Cacoullos NT, Papamichail M, Baxevanis CN. Vaccination with human HER-2/neu (435-443) CTL peptide induces effective antitumor immunity against HER-2/neu-expressing tumor cells in vivo. Cancer Res. 2006;66(10):5452-60.

Submit your next manuscript to BioMed Central and we will help you at every step:

- We accept pre-submission inquiries

- Our selector tool helps you to find the most relevant journal

- We provide round the clock customer support

- Convenient online submission

- Thorough peer review

- Inclusion in PubMed and all major indexing services

- Maximum visibility for your research

Submit your manuscript at www.biomedcentral.com/submit 